Article

\title{
Current Production Capability of Drug-Resistant Pathogen Enables Its Rapid Label-Free Detection Applicable to Wastewater-Based Epidemiology
}

\author{
Waheed Miran ${ }^{1,2} \mathbb{D}$, Xizi Long ${ }^{2}$, Wenyuan Huang ${ }^{2,3} \mathbb{D}$ and Akihiro Okamoto ${ }^{2,3, *(\mathbb{D})}$ \\ 1 School of Chemical and Materials Engineering, National University of Sciences and Technology, \\ Islamabad 44000, Pakistan; waheed.miran@scme.nust.edu.pk \\ 2 International Center for Materials Nanoarchitectonics (WPI-MANA), National Institute for Materials Science, \\ 1-1 Namiki, Tsukuba 305-0044, Japan; long.xizi@nims.go.jp (X.L.); huang.wenyuan@nims.go.jp (W.H.) \\ 3 Graduate School of Chemical Sciences and Engineering, Hokkaido University, North 13 West 8, Kita-ku, \\ Sapporo 060-8628, Japan \\ * Correspondence: okamoto.akihiro@nims.go.jp
}

check for

updates

Citation: Miran, W.; Long, X.; Huang, W.; Okamoto, A. Current Production Capability of Drug-Resistant Pathogen Enables Its Rapid Label-Free Detection Applicable to Wastewater-Based Epidemiology.

Microorganisms 2022, 10, 472.

https://doi.org/10.3390/

microorganisms 10020472

Academic Editor:

Mohammad Katouli

Received: 29 December 2021

Accepted: 11 February 2022

Published: 20 February 2022

Publisher's Note: MDPI stays neutral with regard to jurisdictional claims in published maps and institutional affiliations.

Copyright: () 2022 by the authors. Licensee MDPI, Basel, Switzerland. This article is an open access article distributed under the terms and conditions of the Creative Commons Attribution (CC BY) license (https:// creativecommons.org/licenses/by/ $4.0 /)$.

\begin{abstract}
A rapid and label-free method for the detection of drug-resistant pathogens is in high demand for wastewater-based epidemiology. As recently shown, the extent of electrical current production $\left(I_{c}\right)$ is a useful indicator of a pathogen's metabolic activity. Therefore, if drug-resistant bacteria have extracellular electron transport (EET) capability, a simple electric sensor may be able to detect not only the growth as a conventional plating technique but also metabolic activity specific for drug-resistant bacteria in the presence of antibiotics. Here, one of the multidrug-resistant pathogens in wastewater, Klebsiella pneumoniae, was shown to generate $I_{C}$, and the extent of $I_{\mathcal{C}}$ was unaffected by the microbial growth inhibitor, kanamycin, while the current was markedly decreased in environmental EET bacteria Shewanella oneidensis. Kanamycin differentiated $I_{\mathcal{C}}$ in K. pneumonia and S. oneidensis within $3 \mathrm{~h}$. Furthermore, the detection of K. pneumoniae was successful in the presence of $S$. oneidensis in the electrochemical cell. These results clarify the advantage of detecting drug-resistant bacteria using whole-cell electrochemistry as a simple and rapid method to detect on-site drug-resistant pathogens in wastewater, compared with conventional colony counting, which takes a few days.
\end{abstract}

Keywords: antibiotic-resistant pathogen; wastewater-based epidemiology; whole-cell electrochemistry; single-potential amperometry; extracellular electron transport

\section{Introduction}

Because of the extensive use of antibiotics for treating human and animal infectious ailments, an enormous amount of antibiotics of therapeutic origin are found in various anthropic environments, such as sewage and wastewater treatment plants [1,2]. The widespread use of antibiotics has led to the spread of antibiotic-resistant pathogens, which currently represent a major public health concern [3,4]. Therefore, the risk of drug-resistant bacterial pathogens in wastewater compels the monitoring of wastewater for different types of microbial pathogens. For an appropriate risk assessment, an effective tool that is inexpensive, rapid, label-free, easy to perform, and can be run in high numbers for the detection of drug-resistant pathogens in wastewater bodies is in great demand [5]. Wastewater-based epidemiology can be a very useful methodology for government agencies for estimating the prevalence of antibiotic-resistant pathogens, especially in developing countries where such information is scarce due to financial limitations and the lack of well-structured investigations and surveillance [6]. Current techniques, such as agar plating, and polymerase chain reaction, used for the detection of different types of drugresistant microbial pathogens contaminating water and wastewater, are time-consuming and expensive $[7,8]$. 
Recently, electrical current production via extracellular electron transport (EET) has been shown to indicate metabolic activity $[9,10]$. Monitoring the generation of electrical current as an indicator of cellular metabolic activity in pathogens represents a new direction for research aimed at assessing and screening the effects of antimicrobials on pathogenic metabolic activity [11]. Therefore, if drug-resistant bacteria have EET capability, the simple electric sensor may be able to detect not only the growth but also the metabolic activity specific for drug-resistant bacteria in the presence of antibiotics and can be a new tool for pathogen detection without gene engineering and labeling [12].

In the present work, we conducted a whole-cell electrochemical assay using Klebsiella pneumoniae, a pathogen frequently found in wastewater streams, and Shewanella oneidensis MR1, a model environmental bacterium. We selected a multi-drug-resistant K. pneumoniae, which is a common hospital-acquired pathogen that causes contagions with large morbidity and mortality rates as high as 50\% [13]. Furthermore, the K. pneumoniae resistome evolves under antibiotic and biocide selective pressures, resulting in extremely drug-resistant or high-risk clones, with huge epidemic potential [14]. For control experiments, a non-drugresistant environmental EET-capable model strain Shewanella oneidensis MR1 was selected, and the impact of the drug on the current production of both bacteria was determined.

\section{Materials and Methods}

\subsection{Cell Culture Preparation}

Klebsiella Pneumonia KPNIH1, obtained from Manoil Lab (Washington University, Seattle, WA, USA), was precultivated in $30 \mathrm{~mL}$ Luria-Bertani (LB) broth medium, in $50 \mathrm{~mL}$ falcon tubes at $37^{\circ} \mathrm{C}$. The cells were grown until late exponential growth phase followed by centrifugation at $7800 \mathrm{rpm}$ for $10 \mathrm{~min}$, and the resultant cell pellet was washed with minimal defined medium (DM) twice. DM was composed of $2.5 \mathrm{~g} / \mathrm{L} \mathrm{NaHCO}_{3}, 0.08 \mathrm{~g} / \mathrm{L}$ $\mathrm{CaCl}_{2} \cdot 2 \mathrm{H}_{2} \mathrm{O}, 1.0 \mathrm{~g} / \mathrm{L} \mathrm{NH} \mathrm{Cl}_{4} 0.2 \mathrm{~g} / \mathrm{L} \mathrm{MgCl} \cdot 6 \mathrm{H}_{2} \mathrm{O}, 10.0 \mathrm{~g} / \mathrm{L} \mathrm{NaCl}, 7.2 \mathrm{~g} / \mathrm{L}$ HEPES.

S. oneidensis MR-1 was cultured with $10 \mathrm{~mL} \mathrm{LB}$ medium at $30^{\circ} \mathrm{C}$ for $20 \mathrm{~h}$ in aerobic conditions by picking a single colony from LB solid medium plate. Then the bacteria were washed twice using DM. The cells were centrifuged at $7800 \times g$ for $10 \mathrm{~min}$, followed by supernatant removal. Cell pellets obtained after centrifugation were resuspended in $10 \mathrm{~mL}$ $\mathrm{DM}$. To remove the reductive energy, cells were pre-cultured in the DM for $4 \mathrm{~h}$ within the anaerobic condition and then washed by DM medium. Finally, cell OD was adjusted to the required values by $\mathrm{DM}$ as the final concentration in electrochemical cells.

\subsection{Whole-Cell Electrochemical Analysis}

Electrochemical measurements were conducted in a single-chamber, three-electrode system consisting of an indium tin-doped oxide (ITO) glass substrate (surface area of $\left.3.1 \mathrm{~cm}^{2}\right)$ as the working electrode at the bottom of the glass chamber, and $\mathrm{Ag} / \mathrm{AgCl}(\mathrm{KCl}$ saturated) and a platinum wire, which were used as reference and counter electrodes, respectively $[15,16]$. We used $5 \mathrm{~mL}$ DM containing $10 \mathrm{mM}$ glucose as an electrolyte, and the solution was purged with $\mathrm{N}_{2}$ gas for at least $15 \mathrm{~min}$ to remove the dissolved oxygen in the electrochemical cell. The cell collected from the growth medium after centrifugations were adjusted to the required $\mathrm{OD}_{600}(0.001$ to 0.5$)$ by diluting with DM. Potentiostatic condition of $+0.4 \mathrm{~V}$ vs. a standard hydrogen electrode (SHE) was maintained for single potential amperometry (SA) measurements. During the electrochemical measurements, the reactor temperature was maintained at $37^{\circ} \mathrm{C}$ and operated without agitation. The potentiostat (VMP3, BioLogic Company, Seyssinet-Pariset, France) was used to perform the techniques and measurements, such as SA and differential pulse voltammetry (DPV), as previously described [16,17]. DPV was conducted under the following conditions: $5.0 \mathrm{mV}$ pulse increments, $50 \mathrm{mV}$ pulse amplitude, $300 \mathrm{~ms}$ pulse width, and a $5.0 \mathrm{~s}$ pulse period.

\subsection{Scanning Electron Microscopy}

At the end of the electrochemical experiment, supernatant was removed, and the ITO electrodes were detached from the reactor. Cells were fixed with $2.5 \%$ glutaraldehyde 
and then washed twice with phosphate buffer solution (PBS). The dehydration of washed samples was carried out with 25,50,75,90, and 100\% ethanol gradients in the PBS for 10 min each. Further, samples were dried three times with $\mathrm{t}$-butanol and then freeze-dried under a vacuum system. The samples obtained after freeze-drying were subject to coating with evaporated platinum and subsequently visualized by Keyence VE-9800 microscope.

\subsection{Crystal Violet Staining}

ITO electrodes from the reactor (each reactor had one ITO electrode) before and after the current production experiment were washed three times with PBS to remove the planktonic cells. For the electrode before the current production, we stored the electrode in a cell suspension for $36 \mathrm{~h}$ at $4{ }^{\circ} \mathrm{C}$ to suppress the growth and terminate spontaneous irreversible adhesion to the electrode surface [18]. Cells attached to the ITO surface were stained using $0.1 \%$ crystal violet for $10 \mathrm{~min}$, followed by washing three times with PBS to remove unbound crystal violet. A mixture of acetone and ethanol (3:1) was used to release bound crystal violet. The absorbance value was measured at $595 \mathrm{~nm}$ using an absorption plate reader.

\subsection{Antibiotic Solution}

A stock solution of kanamycin sulfate $50 \mathrm{mg} / \mathrm{mL}$ (dissolved in demineralized water) was purchased from FUJIFILM Wako Pure Chemical Corporation, Osaka, Japan. The stock solution was added to the electrochemical reactor containing bacterial cells and DM to a final concentration of $2 \mathrm{mg} / \mathrm{mL}$. This concentration of kanamycin is considered a lethal concentration for non-drug-resistant pathogens. The antibiotic solution was mixed well in the reactor and kept for at least $30 \mathrm{~min}$ before the start of electrochemical measurements.

\subsection{Live Dead Assay}

BacLight LIVE/DEAD Bacterial Viability Kit (ThermoFisher Scientific, Shibaura, Japan) was used in our experiments to assess live dead bacteria. The kit contains two nucleic dyes, SYTO 9 and propidium iodide (PI). SYTO 9 is a membrane permeant, while PI is a membrane impermeant dye. Saline medium $(0.9 \% \mathrm{NaCl})$ was used for diluting the stock dyes 100 times to make working solutions of SYTO 9 and PI. Prior to fluorescence microscopy, $30 \mu \mathrm{L}$ of the working solution was added to the ITO-attached cells (obtained after the electrochemical experiment) after gentle washing with saline medium. Samples were placed in the dark for $15 \mathrm{~min}$ at room temperature and washed gently with saline medium to remove the excess dyes. Samples were visualized with a Leica DFC45 C epifluorescent microscope.

\section{Results and Discussion}

\subsection{K. pneumoniae Produces Electric Current via Glucose Oxidation}

We first explored the current production capability of K. pneumoniae in a three-electrode electrochemical reactor system using SA. When $10 \mathrm{mM}$ glucose as the sole electron donor was used, K. pneumoniae generated an anodic current at $+0.4 \mathrm{~V}$ (vs. SHE) and an initial $0.1 \mathrm{OD}_{600}$ (Figure 1A). Upon the addition of cells, the current gradually increased to approximately $25 \mathrm{nA} \mathrm{cm}^{2}$ in $12 \mathrm{~h}$, suggesting electron transport. In contrast, there was no current generation without glucose or K. pneumoniae, which is indicative of the current production association with glucose oxidation by K. pneumoniae cells (Figure 1A). DPV measurements were performed to characterize the energy levels of the potential electron transfer pathways between cells and electrodes. DPV measurements showed a clear redox peak at approximately $+10 \mathrm{mV}$ (vs. SHE) with K. pneumoniae in the reactor (Figure 1B). In contrast, no significant peak was observed without cells (Figure 1B), suggesting that K. pneumoniae contained redox agents that potentially mediated electron transport to the electrode surface. The redox potential observed was close to that reported for cytochromes. In addition, half-width potential was broader for outer membrane cytochrome that mediates direct EET mechanisms to electrode surfaces, as in S. oneidensis [16,17], suggesting that K. pneumoniae 
may also be capable of direct electron transfer. However, indirect electron transfer via redox mediators cannot be ruled out; since no further analyses were performed, either a mediator or a protein could be responsible for the redox peak observed. Accordingly, scanning electron microscopy of the ITO electrode surface after current production revealed that cells were attached to the electrode surface (Figure 1C), signifying cell attachment to the electrode surface associated with the oxidative signal in the differential pulse voltammogram. These results strongly suggested that $K$. pneumoniae has a direct EET capacity associated with glucose oxidation metabolism.

A)

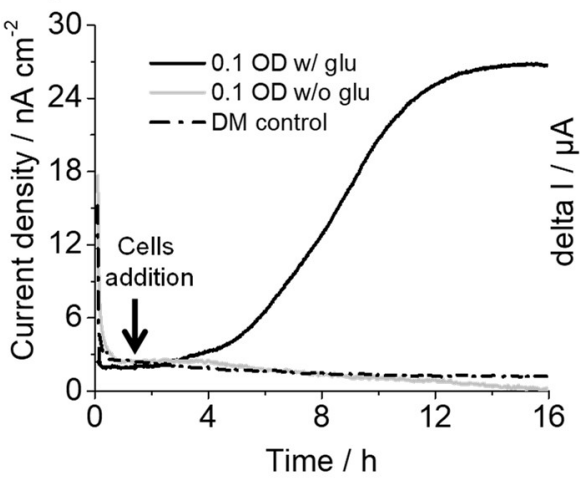

C)

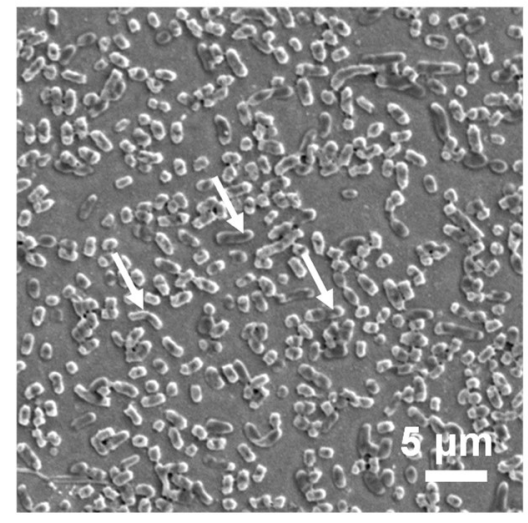

B)
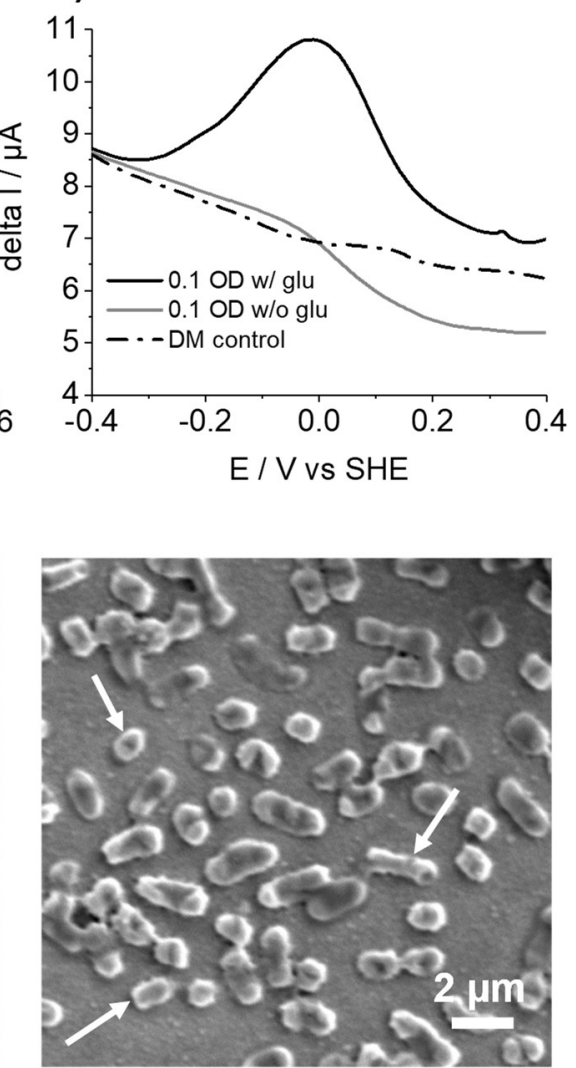

Figure 1. (A) Time course for the current production of K. pneumoniae in the presence of $10 \mathrm{mM}$ glucose on an ITO electrode at $+0.4 \mathrm{~V}$ (vs. SHE). (B) Differential pulse voltammograms for K. pneumoniae on an ITO electrode surface with and without glucose addition at the end of the current measurement experiment. (C) Scanning electron microscopy images of K. pneumoniae cells attached to the electrode surface showing rod-shaped morphology. Arrow indicates cells. Experiments were repeated at least twice, and representative data is presented.

\subsection{K. pneumoniae Grows on the ITO Electrode Surface}

Next, we examined whether the observed current production could associate with the growth of K. pneumoniae cells on the ITO electrode surfacewhen electrode incubation initiate at low cell density. The electrochemical measurements at $+0.4 \mathrm{~V}$ (vs. SHE) and a lower $600 \mathrm{~nm}$ optical density $\left(\mathrm{OD}_{600}\right)$ of 0.01 showed that the current production rise was delayed compared with those at an $\mathrm{OD}_{600}$ of 0.1 (Figure 2A). Maximum current production was only halved, suggesting that the time before the increase and production of the current were limited by the cell density on the ITO electrode. To examine cellular attachment on the ITO electrode, relative quantification of the number of cells attached to the ITO electrode surface was performed using a crystal violet staining assay before and after the current measurement for $36 \mathrm{~h}$. Figure 2B clearly shows that the cell number increased by six folds on the ITO electrode during the current production, compared to a control electrode before 
current production. Accordingly, microscopy confirmed a substantial difference in the number of cells on the electrodes under the same conditions (Figure 2C,D). These results suggested that the current production by K. pneumoniae and its increase are assignable to metabolic activity and cell growth, respectively, in the electrochemical reactor, which can be used to assess the impact of antibiotic agents.

A)

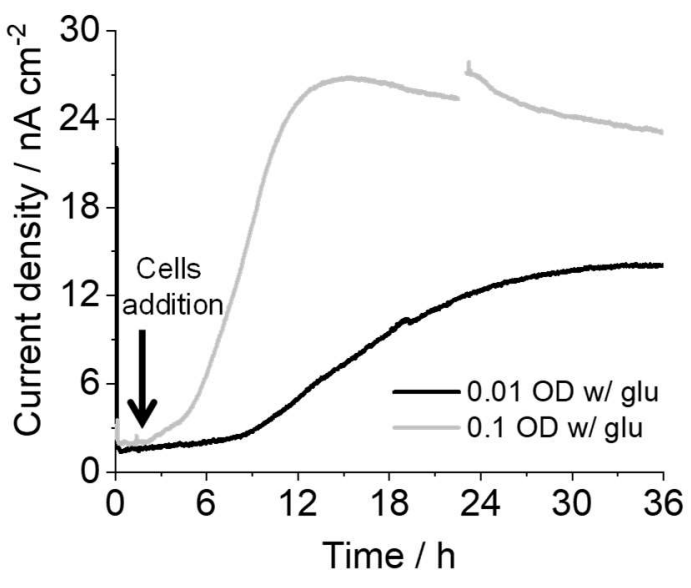

C)

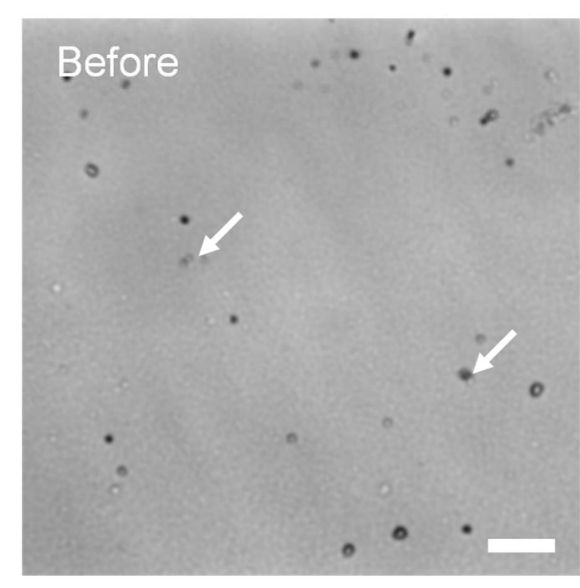

B)

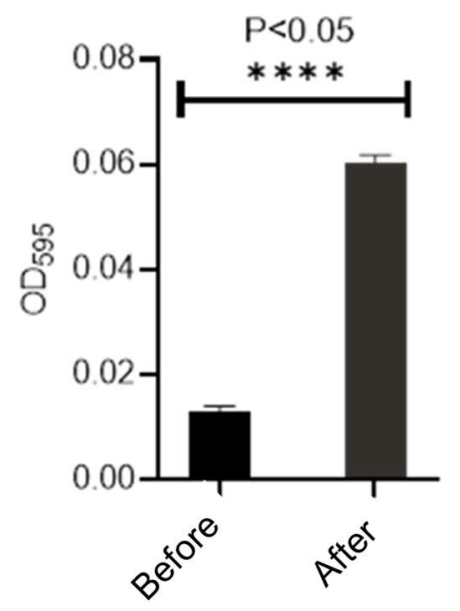

D)

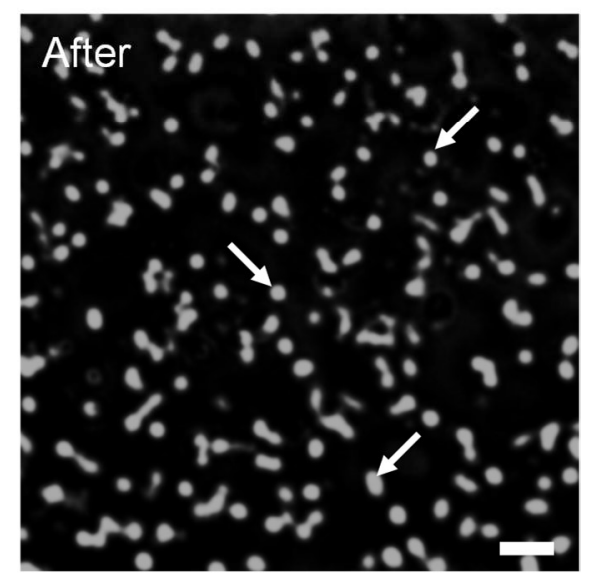

Figure 2. (A) Time course for the current production of $K$. pneumoniae in the presence of $10 \mathrm{mM}$ glucose on an ITO electrode at $+0.4 \mathrm{~V}$ (vs. SHE) initiated with $\mathrm{OD}_{600}$ of 0.1 and 0.01 . (B) Quantification of K. pneumoniae cell numbers using crystal violet staining on the ITO electrode surface before and after current production. One-way analysis of variance with Tukey-Kramer comparison test was performed $\left.{ }^{* * * *} p<0.05\right)$. (C,D) Microscopy images of K. pneumoniae cells before and after current production on the ITO electrode surface. Scale bar, $10 \mu \mathrm{m}$. Arrow indicates cells.

\subsection{Detection of Drug-Resistant Pathogens Using Current Producing Capability}

To examine whether drug resistivity is detectable with the microbial current production associated with metabolic activity, current production was compared between kanamycinresistant K. pneumoniae and $S$. oneidensis in the presence of kanamycin. K. pneumoniae in the presence of $10 \mathrm{mM}$ glucose as the carbon source and an $\mathrm{OD}_{600}$ of 0.1 showed no significant difference with or without kanamycin addition at $2 \mathrm{mg} / \mathrm{mL}$ (Figure 3A), consistent with kanamycin resistance in K. pneumonia. The live-dead assay also showed no substantial difference between the presence and absence of kanamycin (Figure 3B,C). In contrast, the presence of kanamycin at the same concentration suppressed the current production of the non-kanamycin-resistant bacterium $S$. oneidensis, compared with that in 
the absence of kanamycin (Figure 3D). The current production was observed in the first $2 \mathrm{~h}$ in the absence of glucose, suggesting that the initial current production was attributable to the reductive energy from the pre-culture conditions. The live-dead assay confirmed the presence of a large number of dead cells in the presence of kanamycin (Figure 3E,F). Furthermore, the electrochemical detection of K. pneumoniae was also successful in the coculture with S. oneidensis. The current production decreased in the coculture in the presence of kanamycin, and the extent of the decrease was consistent with the current production in a pure culture of S. oneidensis (Figure 3G). While the increase in current was not observed, the current production was continuously observed for $16 \mathrm{~h}$, suggesting that the growth of K. pneumoniae was not clear in the presence of S. oneidensis. However, its metabolic activity was sustained. These results show that microbial current production in antibiotics reflects only the metabolic activity of drug-resistant bacteria.

A)

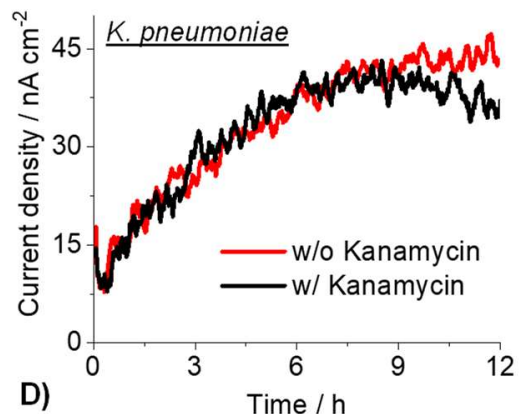

$$
\text { D) }
$$

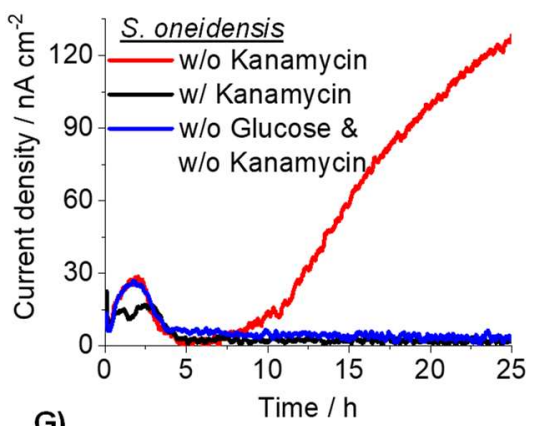

G)

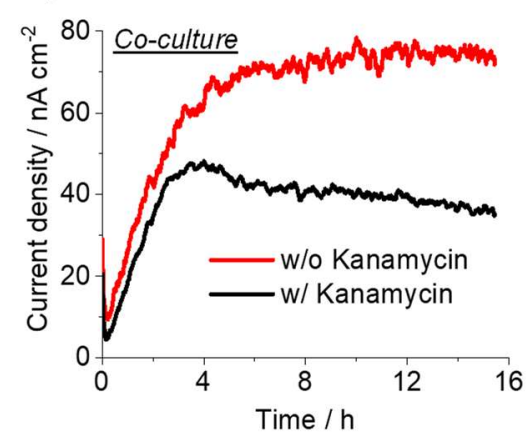

B)
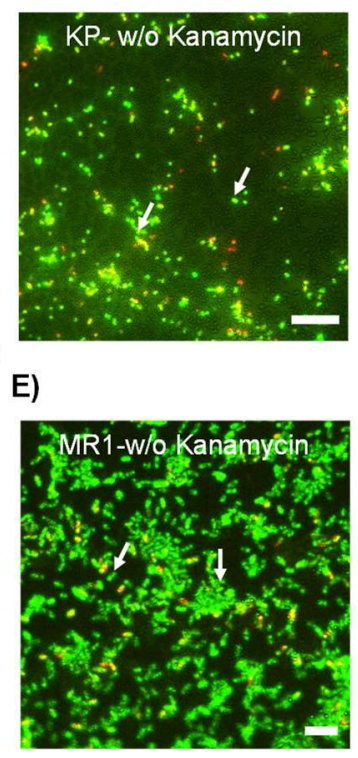

H)

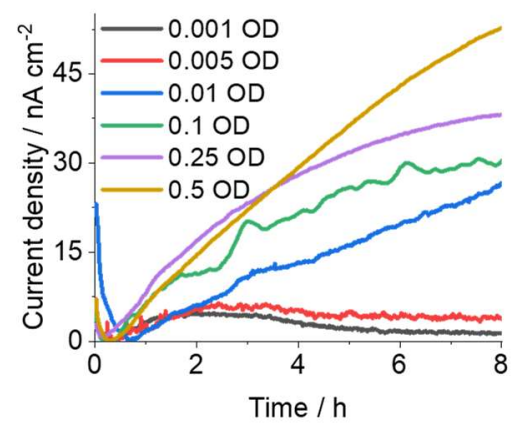

C)

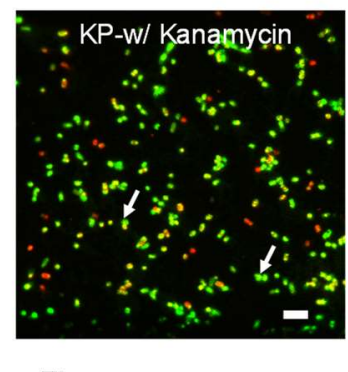

F)

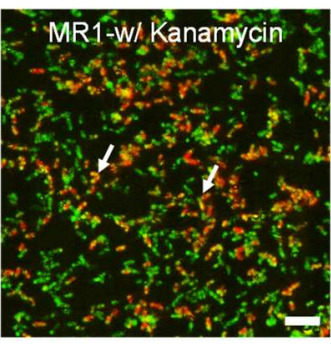

Figure 3. Time course for current production of K. pneumoniae (A) and S. oneidensis (D) in the presence of $10 \mathrm{mM}$ glucose on an ITO electrode at $+0.4 \mathrm{~V}$ (vs. SHE) and an $\mathrm{OD}_{600}$ of 0.1 with and without kanamycin. A mixed population of live and dead K. pneumoniae $(\mathbf{B}, \mathbf{C})$ and S. oneidensis cells $(\mathbf{E}, \mathbf{F})$ stained using the Fluorescence Live/Dead Bacterial Imaging Kit. Live bacteria expressed green fluorescence, while dead cells with damaged membranes expressed red fluorescence. $(\mathbf{B}, \mathbf{E})$ is without kanamycin, while $(\mathbf{C}, \mathbf{F})$ is with kanamycin. Scale bar, $10 \mu \mathrm{m}$. Arrows indicate cells. (G) Time course for current production in the coculture, K. pneumoniae (0.1 OD) and S. oneidensis (0.01 OD) in the presence of $10 \mathrm{mM}$ glucose on an ITO electrode at $+0.4 \mathrm{~V}$ (vs. SHE) with and without kanamycin. (H) Time course for current production from K. pneumoniae in the presence of $10 \mathrm{mM}$ glucose on an ITO electrode at $+0.4 \mathrm{~V}$ (vs. SHE) using an $\mathrm{OD}_{600}$ of 0.001 to 0.5 with kanamycin. 
Finally, we examined the detection limit of K. pneumoniae in the presence of kanamycin. Upon varying the initial cell concentration, the increase in current production was detectable until an $\mathrm{OD}_{600}$ of 0.01 , but not $<0.005$, which was reached in the presence of an antibiotic agent (Figure $3 \mathrm{H}$ ). This suggests that kanamycin impacts the electron transfer to electrode by K. pneumonia at very low cell concentrations. Given that $S$. oneidensis current production was observed in the first $2 \mathrm{~h}$, current production after $3 \mathrm{~h}$ represents the metabolic activity of drug-resistant bacteria, which is considerably shorter than conventional plating methods that require 24 to $72 \mathrm{~h}$ [19]. Therefore, the lowest cell density for differentiating K. pneumonia from S. oneidensis was at an $\mathrm{OD}_{600}$ of 0.01 . For example, if the bacteria from wastewater were concentrated to $\mathrm{OD}_{600} 1.0,1 \%$ K. pneumoniae abundance would be detectable, which is comparable with plating technology [20]. Furthermore, because we used minimum medium DM as an electrolyte to avoid contamination, a richer medium may help to improve the minimum detection limit.

\section{Conclusions}

Our proof-of-concept study based on bioelectrochemical sensors showed that the EETcapable drug-resistant pathogens could be detected by utilizing their current generation ability, which is related to their metabolic activity and not affected by the presence of an inhibitor. The preliminary data from this work shows that the current production capacity of drug-resistant pathogens can help in assessing their presence in a mixture of bacteria by utilizing their cellular metabolism. Compared with plating techniques, current production rapidly detects the presence of drug-resistant bacteria and discriminates between bactericidal and bacteriostatic effects. Furthermore, plate counting underestimates the presence of bacteria as quiescent and viable but not culturable, and nonculturable microorganisms are omitted from the count [21]. Based on our technique, epidemiological data from the field can be effectively used by government agencies for emergency readiness and actions, forecasting disease spread in a population, and building statistical and mechanistic disease models for effective emergency handling [22]. Sensitivity can be overcome by the enhancement of current production with the use of suitable mediators, richly defined medium, or modified electrodes.

Author Contributions: Conceptualization, W.M. and A.O.; methodology, W.M.; software, W.M.; validation, W.M. and A.O.; formal analysis, W.M., X.L. and A.O.; investigation, W.M.; resources, A.O.; data curation, W.M., X.L. and W.H.; writing—original draft preparation, W.M.; writing-review and editing, A.O.; supervision, A.O.; project administration, A.O.; funding acquisition, A.O. All authors have read and agreed to the published version of the manuscript.

Funding: The financial support for this work was provided by a Grant-in-Aid for Research from the Japan Society for Promotion of Science KAKENHI (Grant Nos. 20H05590) and PRIME, the Japan Agency for Medical Research and Development (19gm6010002h0004). This work was also supported by JST, PRESTO Grant Number JPMJPR19H1, Japan, and by JAEA Nuclear Energy S\&T and Human Resource Development Project through concentrating wisdom Grant Number JPJA20P20333393.

Institutional Review Board Statement: Not applicable.

Informed Consent Statement: Not applicable.

Conflicts of Interest: The authors declare no conflict of interest.

\section{References}

1. Turolla, A.; Cattaneo, M.; Marazzi, F.; Mezzanotte, V.; Antonelli, M. Antibiotic resistant bacteria in urban sewage: Role of full-scale wastewater treatment plants on environmental spreading. Chemosphere 2018, 191, 761-769. [CrossRef] [PubMed]

2. Popa, L.I.; Gheorghe, I.; Barbu, I.C.; Surleac, M.; Paraschiv, S.; Măruţescu, L.; Popa, M.; Pîrcălăbioru, G.G.; Talapan, D.; Niţă, M.; et al. Multidrug Resistant Klebsiella pneumoniae ST101 Clone Survival Chain from Inpatients to Hospital Effluent after Chlorine Treatment. Front. Microbiol. 2021, 11, 610296. [CrossRef]

3. Zhang, Z.; Li, B.; Li, N.; Sardar, M.F.; Song, T.; Zhu, C.; Lv, X.; Li, H. Effects of UV disinfection on phenotypes and genotypes of antibiotic-resistant bacteria in secondary effluent from a municipal wastewater treatment plant. Water Res. 2019, 157, 546-554. [CrossRef] [PubMed] 
4. Lorenzo, P.; Adriana, A.; Jessica, S.; Carles, B.; Marinella, F.; Marta, L.; Luis, B.J.; Pierre, S. Antibiotic resistance in urban and hospital wastewaters and their impact on a receiving freshwater ecosystem. Chemosphere 2018, 206, 70-82. [CrossRef] [PubMed]

5. Madhusoodanan, J. Innovative tools take aim at antibiotic-resistant microbes. Nature 2021, 596, 611-613. [CrossRef]

6. Archer, E.; Castrignanò, E.; Kasprzyk-Hordern, B.; Wolfaardt, G.M. Wastewater-based epidemiology and enantiomeric profiling for drugs of abuse in South African wastewaters. Sci. Total Environ. 2018, 625, 792-800. [CrossRef]

7. Mao, K.; Zhang, H.; Pan, Y.; Yang, Z. Biosensors for wastewater-based epidemiology for monitoring public health. Water Res. 2021, 191, 116787. [CrossRef]

8. El-Liethy, M.; El-Taweel, G.; El-Sonosy, W.; Samhan, F.; Moussa, T. Determination of pathogenic bacteria in wastewater using conventional and PCR techniques. Environ. Biotechnol. 2009, 5, 73-80.

9. Naradasu, D.; Guionet, A.; Miran, W.; Okamoto, A. Microbial current production from Streptococcus mutans correlates with biofilm metabolic activity. Biosens. Bioelectron. 2020, 162, 112236. [CrossRef]

10. Naradasu, D.; Miran, W.; Okamoto, A. Metabolic Current Production by an Oral Biofilm Pathogen Corynebacterium matruchotii. Molecules 2020, 25, 3141. [CrossRef]

11. Miran, W.; Naradasu, D.; Okamoto, A. Pathogens electrogenicity as a tool for in-situ metabolic activity monitoring and drug assessment in biofilms. iScience 2021, 24, 102068. [CrossRef] [PubMed]

12. Cesewski, E.; Johnson, B.N. Electrochemical biosensors for pathogen detection. Biosens. Bioelectron. 2020, 159, 112214. [CrossRef]

13. Bassetti, M.; Giacobbe, D.R.; Giamarellou, H.; Viscoli, C.; Daikos, G.L.; Dimopoulos, G.; De Rosa, F.G.; Giamarellos-Bourboulis, E.J.; Rossolini, G.M.; Righi, E.; et al. Management of KPC-producing Klebsiella pneumoniae infections. Clin. Microbiol. Infect. 2018, 24, 133-144. [CrossRef] [PubMed]

14. Navon-Venezia, S.; Kondratyeva, K.; Carattoli, A. Klebsiella pneumoniae: A major worldwide source and shuttle for antibiotic resistance. FEMS Microbiol. Rev. 2017, 41, 252-275. [CrossRef] [PubMed]

15. Tokunou, Y.; Hashimoto, K.; Okamoto, A. Acceleration of Extracellular Electron Transfer by Alternative Redox-Active Molecules to Riboflavin for Outer-Membrane Cytochrome c of Shewanella oneidensis MR-1. J. Phys. Chem. C 2016, 120, 16168-16173. [CrossRef]

16. Okamoto, A.; Hashimoto, K.; Nealson, K.H.; Nakamura, R. Rate enhancement of bacterial extracellular electron transport involves bound flavin semiquinones. Proc. Natl. Acad. Sci. USA 2013, 110, 7856. [CrossRef]

17. Tokunou, Y.; Hashimoto, K.; Okamoto, A. Electrochemical Detection of Deuterium Kinetic Isotope Effect on Extracellular Electron Transport in Shewanella oneidensis MR-1. J. Vis. Exp. 2018, 134, e57584. [CrossRef] [PubMed]

18. Zeraik, A.; Nitschke, M. Influence of growth media and temperature on bacterial adhesion to polystyrene surfaces. Braz. Arch. Biol. Technol. 2012, 55, 569-576. [CrossRef]

19. Cichocki, N.; Hübschmann, T.; Schattenberg, F.; Kerckhof, F.-M.; Overmann, J.; Müller, S. Bacterial mock communities as standards for reproducible cytometric microbiome analysis. Nat. Protoc. 2020, 15, 2788-2812. [CrossRef] [PubMed]

20. Lindqvist, R.; Barmark, G. Specific growth rate determines the sensitivity of Escherichia coli to lactic acid stress: Implications for predictive microbiology. Biomed. Res. Int. 2014, 2014, 471317. [CrossRef]

21. Chen, Y.; Pouillot, R.; Burall, S.L.; Strain, E.A.; Van Doren, J.M.; De Jesus, A.J.; Laasri, A.; Wang, H.; Ali, L.; Tatavarthy, A.; et al. Comparative evaluation of direct plating and most probable number for enumeration of low levels of Listeria monocytogenes in naturally contaminated ice cream products. Int. J. Food Microbiol. 2017, 241, 15-22. [CrossRef] [PubMed]

22. Fairchild, G.; Tasseff, B.; Khalsa, H.; Generous, N.; Daughton, A.R.; Velappan, N.; Priedhorsky, R.; Deshpande, A. Epidemiological Data Challenges: Planning for a More Robust Future Through Data Standards. Front. Public Health 2018, 6, 336. [CrossRef] [PubMed] 